ISSN 1420-3049

www.mdpi.com/journal/molecules

Article

\title{
Synthesis and Adrenolytic Activity of New Propanolamines
}

\section{Grażyna Groszek $^{1, *}$, Agata Bajek ${ }^{1}$, Agnieszka Bis ${ }^{1}$, Agnieszka Nowak-Król ${ }^{1}$, Marek Bednarski ${ }^{2}$, Agata Siwek $^{3}$ and Barbara Filipek ${ }^{2, *}$}

1 Faculty of Chemistry, Rzeszów University of Technology, 6 Powstańców Warszawy Avenue, 35 959 Rzeszów, Poland

2 Laboratory of Pharmacological Screening, Jagiellonian University Medical College, 9 Medyczna, 30-689 Kraków, Poland

3 Department of Pharmacobiology, Jagiellonian University Medical College, 9 Medyczna, 30-689 Kraków, Poland

* Authors to whom correspondence should be addressed; E-Mails: ggroszek@prz.edu.pl (G.G.); mffilipe@cyf-kr.edu.pl (B.F.); Tel.: +48 17 8651751(G.G.); +48 126205531(B.F.); Fax: +48 178543655 (G.G.); +48 126205552 (B.F.).

Received: 20 April 2010; in revised form: 23 May 2010 / Accepted: 26 May 2010 / Published: 28 May 2010

\begin{abstract}
The synthesis of (2R,S)-1-(6-methoxy-4-(methoxymethyl)-1H-indol-5-yloxy)-3(2-(2-methoxyphenoxy)ethylamino)propan-2-ol and (2R,S)-1-(4-methoxy-6-(methoxymethyl)-1H-indol-5-yloxy)-3-(2-(2-methoxyphenoxy)ethylamino)propan-2-ol is described. The compounds were tested for electrographic, antiarrhythmic, hypotensive, and spasmolytic activity, as well as for $\alpha_{1^{-}}, \alpha_{2}$ - and $\beta_{1}$-adrenoceptor binding affinity.
\end{abstract}

Keywords: $\alpha_{1}$-andrenoceptor antagonist; synthesis; pharmacology

\section{Introduction}

In our search for new aminopropan-2-ol derivatives with cardiovascular activity among, we obtained the compound (2R,S)-1-(1H-indol-4-yloxy)-3-(2-(2-methoxyphenoxy)ethylamino)propan-2ol, (R,S)-9 (Figure 1) [1] which became a lead structure for further investigations. The compound (R,S)-9 possesses $\alpha_{1^{-}}$and $\beta_{1}$-adrenolytic, antiarrhythmic, and hypotensive activities similar to carvedilol, which is a very effective compound in the treatment of such cardiovascular diseases as 
hypertension, heart failure, and stable angina pectoris. Carvedilol also decreases secondary cardiac events after myocardial infarction (MI) and reduces infarct size after myocardial ischemic and reperfusion injury [2].

Figure 1. Chemical structure of the compound $(\boldsymbol{R}, S)-9$.



Several adrenergic drive indices, such as plasma norepinephrine, norepinephrine spillover from adrenergic nerve terminals and efferent postganglionic muscle sympathetic nerve traffic, have all shown an increase in the different conditions clustering in metabolic syndrome, such as obesity, hypertension and insulin resistance state [3]. The effects of catecholamines are of clinical significance because they lead to the final common pathway underlying cardiovascular events atherogenesis. The blockade of the $\alpha_{1}$-AR may result in an improvement in the metabolic profile of the diabetic hypertensive patient, as recently seen in the GEMINI trial. Catecholamines also decrease LDL receptors and lipoprotein lipase activity, and inhibit extrahepatic cholesterol synthesis so modulation of catecholamine activity may have an important role in determining the level of cholesterol [4].

$\beta$-Blockers, nonselective and $\beta_{1}$ selective may promote atherogenic lipid changes as well as increased insulin resistance and glucose and insulin blood levels; $\beta$-blocker use has been associated with the degradation of glycemic control in diabetic patients and an increase in the rate of new-onset diabetes in nondiabetic patients. In contrast, carvedilol use has been associated with a beneficial or neutral effect on blood lipid levels and insulin sensitivity [5].

The aim of this study was the synthesis and evaluation of the cardiovascular activity of two new aminopropan-2-ol derivatives: (2R,S)-1-(6-methoxy-4-(methoxymethyl)-1H-indol-5-yloxy)-3-(2-(2methoxyphenoxy)ethylamino)propan-2-ol and (2R,S)-1-(4-methoxy-6-(methoxymethyl)-1H-indol-5yloxy)-3-(2-(2-methoxyphenoxy)ethylamino)propan-2-ol (Figure 2). The tested compounds are structural analogs of compound (R,S)-9, and other compounds described in the previous articles [6]. However here, aminopropanol moiety is situated in the 5-position of the indole moiety and what is more, the indole ring contains two different substituents, methoxy- and methoxymethyl.

\section{Results and Discussion}

\subsection{Chemistry}

The synthesis of target compounds is outlined in Figure 2. Commercially available 2,3dimethoxybenzaldehyde was nitrated using fuming nitric acid in acetic acid to produce two nitrobenzaldehyde derivatives - the 5-nitro-isomer $\mathbf{1}$ and its regioisomer, 2,3-dimethoxy-6nitrobenzaldehyde in a 1:0.78 ratio, respectively. They were readily separated by column chromatography on silica gel. The latter was used in another project to obtain an indole derivative [6]. 
Selective monodemethylation of compound 1 with $\mathrm{BBr}_{3}$ followed by benzylation of the phenolic hydroxyl group led to $\mathbf{2}$ in $75 \%$ yield. Reduction of the aldehyde derivative $\mathbf{2}$ was achieved with the combined $\mathrm{Bu}_{3} \mathrm{SnH}-\mathrm{HMPA}$ system as described by Shibata et al. [7]. The method is suitable for benzaldehyde derivatives bearing other reducible functional groups such as nitro. Attempts to utilize the obtained benzyl alcohol derivative for further reaction such as $O$-methylation in a one pot procedure have failed. In our case it turned out that standard work-up had to be done after reduction of aldehyde and before the alkylation step. Then, $O$-alkylation became possible and was performed using $\mathrm{NaH}$ and $\mathrm{MeI}$ in $\mathrm{THF}$ at $5{ }^{\circ} \mathrm{C}$ to room temperature. Compound 3 was obtained in a yield of $78 \%$. Vicarious nucleophilic substitution of hydrogen [8] in the nitrobenzene derivative 3 with (4-chlorophenoxy)acetonitrile in the presence of potassium $t$-butoxide in DMF gave two regioisomers 4 and 5, containing the cyanomethyl substituent in positions ortho to the nitro group. They were separated via column chromatography on silica gel. For intermediates $\mathbf{4}$ and $\mathbf{5}$, the yields were $29 \%$ and $43 \%$, respectively. Both isomers were converted to the hydroxyindole derivatives 6 and 7 in $67 \%$ yield by means of reductive cyclization of the corresponding cyanomethyl derivatives. In the ${ }^{1} \mathrm{H}-\mathrm{NMR}$ spectrum of compounds 6 and 7, the aromatic proton in position 3- appeared as multiplets at 6.47-6.48, and 6.46-6.47 ppm, respectively. The proton in position 2- appeared as an apparent triplet

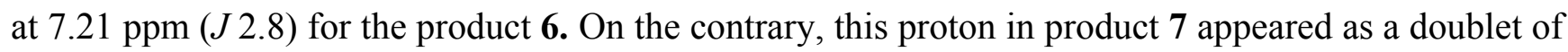
doublets at $7.12 \mathrm{ppm}$ ( $J 3.1$ and 2.5). The phenolic hydroxyl was situated in position 5- of the indole framework. As described in the previous paper [1], compounds 6 and 7 were transformed by condensation with (+/-)-epichlorohydrin. The epoxide derivatives 8 and 9 were formed and then converted to the aminoalcohols 10 and 11 by addition reaction of 2-(2-methoxyphenoxy)ethylamine to the epoxide function. The epoxides 8 and 9 were obtained in yields of $44 \%$ to $64 \%$, and the aminoalcohol derivatives $\mathbf{1 0}$ and $\mathbf{1 1}$ in yields of $70 \%$ and $68 \%$, respectively.

Figure 2. Synthetic pathway.<smiles>COc1cccc(C(=O)[CH]Oc2cc([N+](=O)[O-])cc(C=O)c2OC)c1OC</smiles>

1<smiles>COc1cc([N+](=O)[O-])cc(C=CC(C)C)c1OCc1ccccc1</smiles>

2

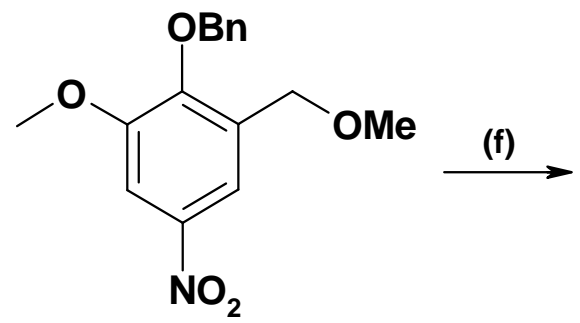

3<smiles>COCc1cc([N+](=O)[O-])c(CC#N)c(OC)c1OCc1ccccc1</smiles>

4<smiles>COCc1c(CC#N)c(OC)cc([N+](=O)[O-])c1OCc1ccccc1</smiles>

5 
Figure 2. Cont.<smiles>COCc1cc2[nH]ccc2c(OC)c1O</smiles>

6

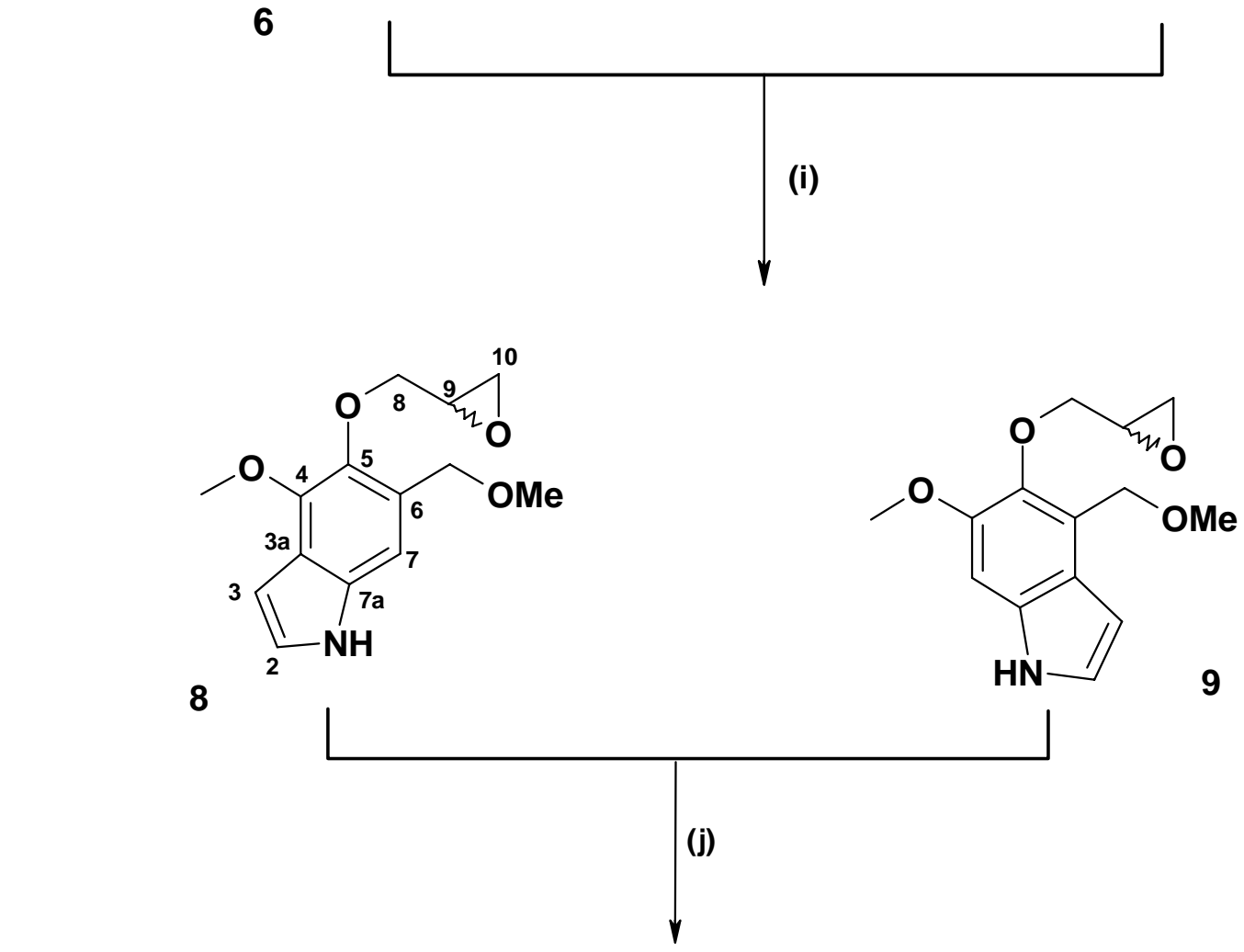

7<smiles>COCc1c(OC[C@H](O)CNCCOc2ccccc2OC)c(OC)cc2[nH]ccc12</smiles>

Reagents and Conditions: (a) fuming $\mathrm{HNO}_{3}, \mathrm{AcOH}, 12{ }^{\circ} \mathrm{C}$, two nitro derivative regioisomers were obtained in a 1.0:0.78 ratio corresponding to the positions meta and ortho to the aldehyde group, respectively; (b) $\mathrm{BBr}_{3}, \mathrm{CH}_{2} \mathrm{Cl}_{2}$, at $-78{ }^{\circ} \mathrm{C}$; (c) benzyl chloride, $\mathrm{K}_{2} \mathrm{CO}_{3}, \mathrm{KI}, \mathrm{CH}_{3} \mathrm{CN}$; (d) $\mathrm{Bu}_{3} \mathrm{SnH}$ HMPA, $60{ }^{\circ} \mathrm{C}$, benzene, argon; (e) $\mathrm{NaH}(60 \%)$, THF, MeI, rt, argon; (f) $t$-BuOK, $p$-Cl- $\mathrm{C}_{6} \mathrm{H}_{4}$ $\mathrm{OCH}_{2} \mathrm{CN}$, DMF, $-20{ }^{\circ} \mathrm{C}$; (g) separation on silica gel column; (h) $\mathrm{H}_{2}, 10 \% \mathrm{Pd} / \mathrm{C}$, EtOH/AcOH; (i) (+/-)-epichlorohydrin, $\sim 3 \% \mathrm{NaOH}$ aq., 1,4-dioxane; (j) 2-(2-methoxyphenoxy)ethylamine, $\mathrm{CH}_{3} \mathrm{CN}$, $80{ }^{\circ} \mathrm{C}$. 


\subsection{Pharmacology}

2.2.1. Radioligand receptor binding assay for $\alpha$ - and $\beta$-adrenergic receptors

The affinity of compounds 10 and 11 to the catecholamine binding side of $\alpha_{1^{-}}, \alpha_{2^{-}}$and $\beta_{1^{-}}$ adrenoceptors was measured as a rate of specific displacement of $\left[{ }^{3} \mathrm{H}\right]$ Prazosin, $\left[{ }^{3} \mathrm{H}\right]$ Clonidine and $\left[{ }^{3} \mathrm{H}\right] \mathrm{CGP} 12177$ at the concentrations of $0.2 \mathrm{nM}, 2 \mathrm{nM}$ and $0.2 \mathrm{nM}$, respectively. Compound 11 displaced $\left[{ }^{3} \mathrm{H}\right]$ Prazosin from cortical binding sites in higher concentration than compound 10 $\left(\mathrm{K}_{\mathrm{i}}=21.4 \mathrm{nM}\right.$ and 5,9 nM, respectively) and inhibited $\left[{ }^{3} \mathrm{H}\right]$ Clonidine in lower concentration than compound $10\left(\mathrm{~K}_{\mathrm{i}}=166.5 \mathrm{nM}\right.$ and $306.7 \mathrm{nM}$, respectively). These compounds displaced $\left[{ }^{3} \mathrm{H}\right] \mathrm{CGP} 12177$ from its binding sites in low concentration rate $\left(\mathrm{K}_{\mathrm{i}}=4.2-6.9 \mu \mathrm{M}\right)$. The results are summarized in Table 1.

Table 1. Affinity for different adrenoceptor types in the rat cerebral cortex $\left(\mathrm{K}_{\mathrm{i}}[\mathrm{nM}] \pm \mathrm{SEM}\right)$.

\begin{tabular}{llll}
\hline Compound & {$\left[{ }^{3} \mathbf{H}\right]$ Prazosin } & {$\left[{ }^{3} \mathbf{H}\right]$ Clonidine } & {$\left[{ }^{\mathbf{3}} \mathbf{H}\right] \mathbf{C G P 1 2 1 7 7}$} \\
\hline $\mathbf{1 0}$ & $5.9 \pm 0.3$ & $306.7 \pm 11.7$ & $6.9 \pm 0,8 \mu \mathrm{M}$ \\
$\mathbf{1 1}$ & $21.4 \pm 1.3$ & $166.5 \pm 9.8$ & $4.2 \pm 0,6 \mu \mathrm{M}$ \\
$(R, S)-\mathbf{9}$ & $89.8 \pm 9.5$ & $1.4 \pm 0.4 \mu \mathrm{M}$ & $3.0 \pm 0.6$ \\
Carvedilol & $2.2 \pm 0.2^{\mathrm{a}}$ & $3.4 \pm 0.9 \mu \mathrm{M}$ & $0.81 \pm 0.06^{\mathrm{a}}$ \\
\hline
\end{tabular}

${ }^{\mathrm{a}}$ Ref. [9].

None of the new analogs of compound $(\boldsymbol{R}, \boldsymbol{S})-\mathbf{9}$ displaced [3H]CGP12177 from the cortical binding site at low concentration. Both of them had high affinity to $\alpha$-adrenoceptors and compound $\mathbf{1 0}$ was 52-fold more selective towards $\alpha_{1}$-adrenergic receptors than compound 11 . In the case of $\alpha_{2}$-adrenoceptors, $\mathbf{1 1}$ possessed twice as much affinity as $\mathbf{1 0}$. The affinity to specific receptors may suggest the direction of biological action of the new tested compounds.

\subsubsection{Effect on normal electrocardiogram (ECG) in vivo in rats}

The effects on ECG intervals and heart rate were determined for all tested compounds at the same dose of $1 \mathrm{mg} \cdot \mathrm{kg}^{-1}$. The influence of compound $\mathbf{1 0}$ on the ECG was similar to that observed after administration of compound 11. The tested compounds significantly changed the ECG pattern. They prolonged $\mathrm{P}-\mathrm{Q}, \mathrm{Q}-\mathrm{T}$ intervals, and QRS complex. The compound 11 slightly decreased the number of cardiac beats per minute, up to 15 min after administration (Table 2).

Table 2. Effects of an $i v$ injection of the investigated compounds in dose of $1 \mathrm{mg} \cdot \mathrm{kg}^{-1}$ on heart rate and ECG intervals in anesthetized male Wistar rats $\left(60 \mathrm{mg}\right.$ of thiopental $\left.\cdot \mathrm{kg}^{-1}, \mathrm{ip}\right)$.

\begin{tabular}{llllll}
\hline \multirow{2}{*}{ Compound Parameters } & \multicolumn{4}{c}{ Time of observation (min) } \\
\cline { 2 - 6 } & \multicolumn{1}{c}{$\mathbf{0}$} & \multicolumn{1}{c}{$\mathbf{1}$} & \multicolumn{1}{c}{$\mathbf{5}$} & \multicolumn{1}{c}{$\mathbf{1 5}$} \\
\hline $\mathbf{1 0}$ & P-Q (ms) & $40.4 \pm 0.4$ & $45.6 \pm 1.6^{\mathrm{b}}$ & $46.8 \pm 1.6^{\mathrm{c}}$ & $46.4 \pm 1.6^{\mathrm{c}}$ \\
& QRS (ms) & $27.6 \pm 0.8$ & $31.2 \pm 0.5^{\mathrm{c}}$ & $31.2 \pm 1.0^{\mathrm{c}}$ & $32.4 \pm 0.8^{\mathrm{d}}$ \\
& Q-T (ms) & $94.4 \pm 2.8$ & $92.0 \pm 4.2$ & $100.0 \pm 2.8$ & $104.0 \pm 1.4^{\mathrm{a}}$ \\
& Beats/min & $329.4 \pm 12.2$ & $334.0 \pm 13.0$ & $309.6 \pm 13.7$ & $297.4 \pm 12.4$ \\
\hline
\end{tabular}


Table 2. Cont.

\begin{tabular}{llllll}
\hline 11 & P-Q (ms) & $42.8 \pm 1.2$ & $47.2 \pm 1.0^{\mathrm{c}}$ & $46.8 \pm 0.5^{\mathrm{b}}$ & $48.0 \pm 1.1^{\mathrm{c}}$ \\
& QRS (ms) & $27.2 \pm 1.4$ & $30.4 \pm 0.4^{\mathrm{b}}$ & $31.2 \pm 0.8^{\mathrm{c}}$ & $32.4 \pm 0.8^{\mathrm{d}}$ \\
& Q-T (ms) & $85.2 \pm 0.8$ & $87.2 \pm 1.2$ & $91.2 \pm 3.3$ & $97.2 \pm 2.2^{\mathrm{d}}$ \\
& Beats/min & $337.8 \pm 6.7$ & $332.4 \pm 10.6$ & $320.6 \pm 7.8$ & $310.2 \pm 9.4^{\mathrm{a}}$ \\
$(\boldsymbol{R}, \boldsymbol{S})-\mathbf{9}$ & P-Q (ms) & $45.7 \pm 2.0$ & $47.2 \pm 1.6$ & $48.1 \pm 2.4$ & $46.2 \pm 1.7$ \\
& QRS (ms) & $26.4 \pm 1.3$ & $28.4 \pm 1.2$ & $24.9 \pm 1.3$ & $26.9 \pm 1.1$ \\
& Q-T (ms) & $72.6 \pm 1.7$ & $69.2 \pm 1.1$ & $69.0 \pm 1.6$ & $72.8 \pm 1.3$ \\
& Beats/min & $304.9 \pm 8.9$ & $298.7 \pm 7.2$ & $294.5 \pm 7.7$ & $287.3 \pm 7.9$ \\
Carvedilol & P-Q (ms) & $50.0 \pm 3.2$ & $50.0 \pm 3.2$ & $55.0 \pm 5.5$ & $54.6 \pm 3.0$ \\
& QRS (ms) & $21.2 \pm 0.8$ & $22 \pm 0.6$ & $22.8 \pm 1.0$ & $23.2 \pm 0.8$ \\
& Q-T (ms) & $72.0 \pm 3.1$ & $74.4 \pm 2.8$ & $68.0 \pm 3.7$ & $74.0 \pm 2.4$ \\
& Beats/min & $356.7 \pm 21.0$ & $345.2 \pm 17.7$ & $340.3 \pm 14.8$ & $320.4 \pm 10.2$ \\
\hline
\end{tabular}

Values are the mean \pm SEM of 6 experiments; The statistical analyses were performed using a oneway ANOVA test; ${ }^{\mathrm{a}} \mathrm{p}<0.05 ;{ }^{\mathrm{b}} \mathrm{p}<0.02 ;{ }^{\mathrm{c}} \mathrm{p}<0.01 ;{ }^{\mathrm{d}} \mathrm{p}<0.001$.

The electrocardiographic changes observed after administration of these compounds were similar to those seen after administration of quinidine [10]. These quinidine-like properties also known as membrane stabilizing activities could partially cause the antiarrhythmic activities of the tested compounds.

\subsubsection{Effect on adrenaline-induced arrhythmia in rats}

The prophylactic antiarrhythmic activity of compounds $\mathbf{1 0}$ and $\mathbf{1 1}$ was determined using an adrenaline-induced arrhythmia model of in anesthetized rats. Intravenous injections of adrenaline at a dose of $20 \mu \mathrm{g} \cdot \mathrm{kg}^{-1}$ caused reflex bradycardia (100\%), supraventricular and ventricular extrasystoles $(100 \%)$, bigeminy in rats, which led to the death of approximately $50 \%$ of the test animals. The $\mathrm{ED}_{50}$ values (a dose producing 50\% inhibition of premature ventricular beats) are presented in Table 3 .

Table 3. The prophylactic antiarrhythmic activity in anesthetized rats.

\begin{tabular}{lll}
\hline Compound & $\begin{array}{l}\text { ED } \mathbf{5 0} \text { iv } \\
\left(\mathbf{m g} \cdot \mathbf{k g}^{-\mathbf{1}}\right)\end{array}$ & $\begin{array}{l}\mathbf{E D}_{\mathbf{5 0}} \mathbf{p o} \\
\left(\mathbf{m g} \cdot \mathbf{k g}^{-\mathbf{1}}\right)\end{array}$ \\
\hline $\mathbf{1 0}$ & $0.35(0.18-0.72)$ & $1.71(1.52 \pm 1.93)$ \\
$\mathbf{1 1}$ & $0.16(0.10-0.23)$ & $0.86(0.76 \pm 0.96)$ \\
$(\boldsymbol{R}, \boldsymbol{S})-\mathbf{9}$ & $0.34(0.23-0.51)$ & $0.44(0.18 \pm 1.10)$ \\
Carvedilol & $0.25(0.12-0.53)$ & - \\
Propranolol & $1.05(0.64-1.73)^{\mathrm{a}}$ & $19.5(14.5 \pm 26.1)$ \\
\hline \multicolumn{3}{c}{ Ref. [11]. }
\end{tabular}

The tested compounds injected intravenously $15 \mathrm{~min}$ before adrenaline, prevented and/or diminished the number of premature ventricular and supraventricular beats, and reduced mortality. The compound 11 was more active, exhibited important antiarrhythmic effects, and its $\mathrm{ED}_{50}$ value equaled $0.16 \mathrm{mg} \cdot \mathrm{kg}^{-1}$. The $\mathrm{ED}_{50}$ value for compound 11 was about two times lower than that for compound $\mathbf{1 0}$. 
These compounds administered orally (intragastric) $60 \mathrm{~min}$ before adrenaline retained (maintained) antiarrhythmic activity. The $\mathrm{ED}_{50}$ value equaled $0.86 \mathrm{mg} \cdot \mathrm{kg}^{-1}$ and $1.71 \mathrm{mg} \cdot \mathrm{kg}^{-1}$, for compounds 11 and 10, respectively. In cardiac myocytes, stimulation of $\beta$-adrenergic receptors increased the magnitude of $\mathrm{I}_{\mathrm{Ca}-\mathrm{L}}\left(\mathrm{Ca}^{2+}\right.$ current) via protein kinase A-dependent phosphorylation of the following channels: $\mathrm{I}_{\mathrm{f}}$ (an inward current carried by $\mathrm{Na}^{+}$and $\mathrm{K}^{+}$), $\mathrm{I}_{\mathrm{Cl}}$ (induced $\mathrm{Cl}^{-}$current), $\mathrm{I}_{\mathrm{Kur}}$ (an ultrarapid delayed rectifier $\mathrm{K}^{+}$

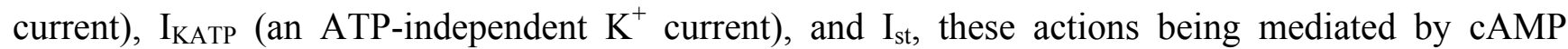
dependent protein kinase [12-14]. The $\beta$-adrenergic stimulation produced by voltage-dependent $\mathrm{Ca}^{2+}$, $\mathrm{I}_{\mathrm{Kur}}$ as well as $\mathrm{Na}^{+}$channels increased the probability of occurrence of a variety of supraventricular and ventricular arrhythmias [15]. The stimulation of $\alpha_{1}$-adrenergic receptors inhibited the $\alpha$-adrenergic activation of the $\mathrm{Cl}^{-}$current [12]. The tested compounds given iv $15 \mathrm{~min}$ before arrhythmogen prevented or attenuated the symptoms of adrenaline-induced arrhythmia. The antiarrhythmic activity of the tested compounds is lower than the effect of carvedilol and compound $(\boldsymbol{R}, \boldsymbol{S})-\mathbf{9}$, and it seems to be related to their adrenolytic properties. These results are in good agreement with previously published data on non-selective and selective $\alpha$-antagonists such as phentolamine, prazosin, and abanoquil which prevented arrhythmia induced by adrenaline or cocaine infusions [16,17]. The obtained results have shown, despite low $\beta$-adrenolytic activities, the antiarrhythmic effect of compounds $\mathbf{1 0}$ and $\mathbf{1 1 .}$

\subsubsection{Influence on blood pressure in rats}

Hypotensive activity of compounds $\mathbf{1 0}$ and $\mathbf{1 1}$ was determined after $i v$ and po administration to normotensive anesthetized rats. Compound 11 significantly decreased the systolic (9-20\%) and diastolic (9-20\%) blood pressure throughout the whole observation period in the range of doses $0.125-1 \mathrm{mg} \cdot \mathrm{kg}^{-1}$ after $i v$ administration.

Figure 3. Changes in mean blood pressure after $i v$ administration of the tested compounds in the lowest effective doses.

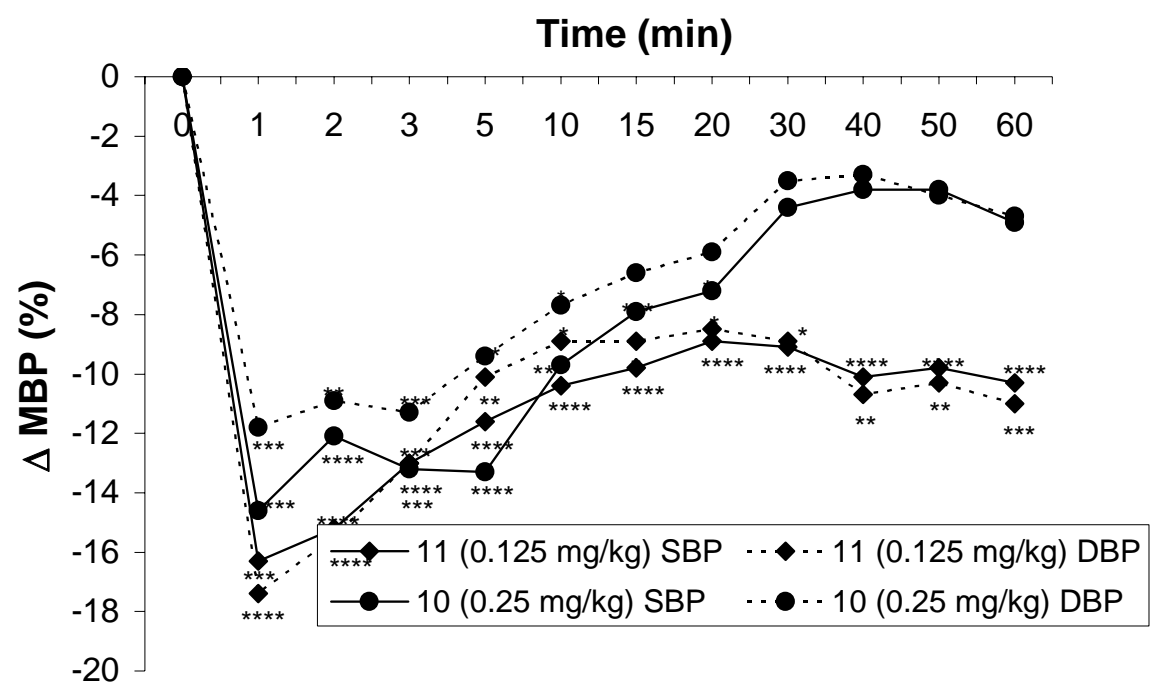

The statistical analyses were performed using a one-way ANOVA test: $* \mathrm{p}<0.05$, $* * \mathrm{p}<0.02, * * * \mathrm{p}<0.01, * * * * \mathrm{p}<0.001$ 
At the lowest dose $\left(0.0625 \mathrm{mg} \cdot \mathrm{kg}^{-1}\right)$ the hypotensive activity of compound $\mathbf{1 1}$ disappeared. Compound 10 at a dose of $0.5 \mathrm{mg} \cdot \mathrm{kg}^{-1}$ significantly decreased systolic blood pressures (8-14\%) throughout the whole observation period and diastolic blood pressure only at the first 10 min after $i v$ administration. At the lower dose $\left(0.25 \mathrm{mg} \cdot \mathrm{kg}^{-1}\right)$ this compound decreased systolic and diastolic blood pressure in 20 and $10 \mathrm{~min}$ after administration, respectively (Figure 3 ).

After po administration the compound 11 in the dose of $0.5 \mathrm{mg} \cdot \mathrm{kg}^{-1}$ significantly decreased systolic (12-16\%) and diastolic (10-13\%) blood pressures from 30 to $70 \mathrm{~min}$ and from 30 to $60 \mathrm{~min}$, respectively. In the lower dose $\left(0.25 \mathrm{mg} \cdot \mathrm{kg}^{-1}\right)$ this compound decreased systolic and diastolic blood pressures from 30 to $90 \mathrm{~min}$, and from 40 to $90 \mathrm{~min}$ after administration, respectively. Hypotensive activity of compound $\mathbf{1 1}$ disappeared in the dose of $0.125 \mathrm{mg} \cdot \mathrm{kg}^{-1}$.

Compound 10 significantly decreased systolic (9-18\%) and diastolic (11-23\%) blood pressures in the dose of $2 \mathrm{mg} \cdot \mathrm{kg}^{-1}$ from 40 to $90 \mathrm{~min}$ after po administration (to the end of the observation period). The hypotensive activity disappeared in the dose of $1 \mathrm{mg} \cdot \mathrm{kg}^{-1}$ of compound $\mathbf{1 0}$ (Figure 4).

Figure 4. Changes in mean blood pressure after po administration of the tested compounds in the lowest effective doses.

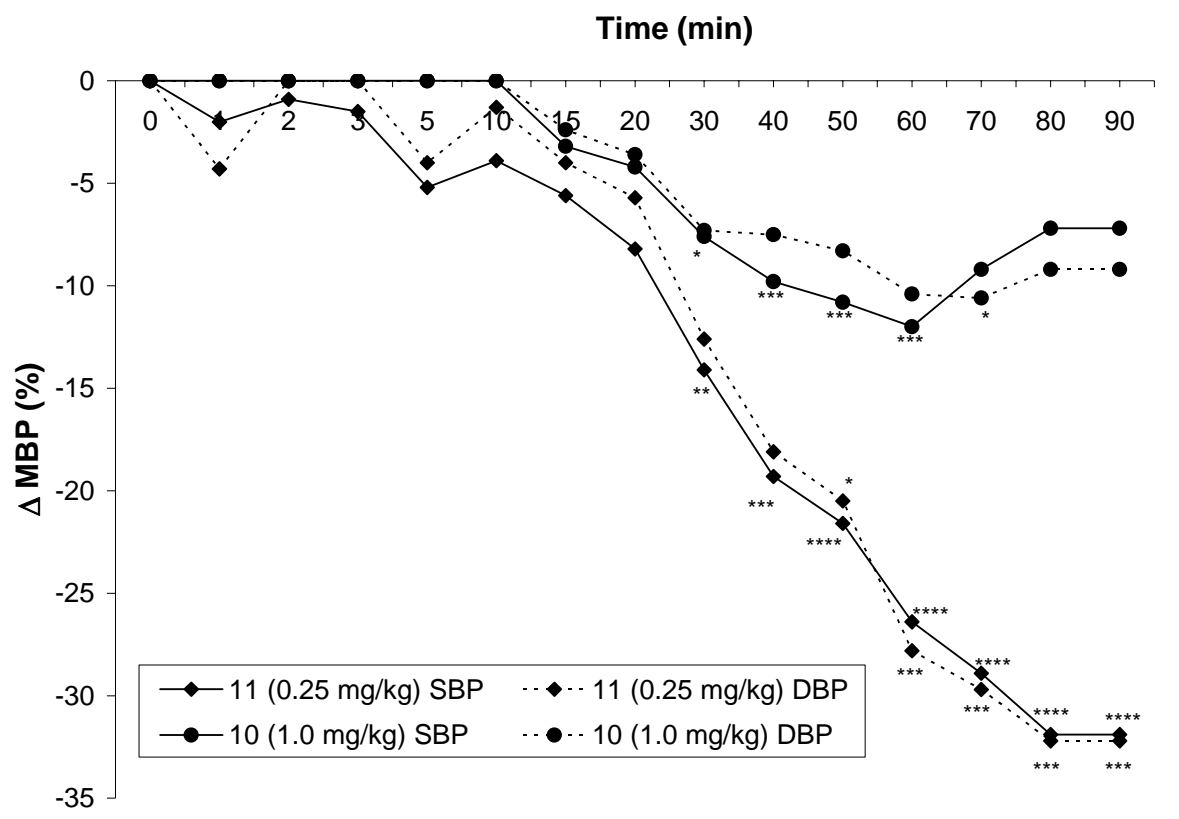

The statistical analyses were performed using a one-way ANOVA test: $* \mathrm{p}<0.05$, $* * \mathrm{p}<0.02, * * * \mathrm{p}<0.01, * * * * \mathrm{p}<0.001$.

Both tested compounds have revealed hypotensive activity after $i v$ and po administration to normotensive rats. Compounds $\mathbf{1 0}$ and $\mathbf{1 1}$ significantly decreased blood pressure throughout the whole observation period at doses of $0.125 \mathrm{mg} \cdot \mathrm{kg}^{-1}$ and $0.5 \mathrm{mg} \cdot \mathrm{kg}^{-1}$ after $i v$ administration. A dose four times larger administered orally maintained the some level of hypotensive action as when administered intravenously. The $\alpha_{1}$-adrenoreceptor blockade in blood vessels is probably caused by hypotensive activity. Classic $\alpha_{1}$-antagonist prazosins proved to be a highly effective antihypertensive drug, and its congeners, doxazosin and terazosin, which offer similar pharmacology with a longer duration of action, remain important options in the treatment regimen available for hypertension. In addition to blood pressure reduction, $\alpha_{1}$-antagonists offer the advantages of a favourable effect on plasma 
lipoproteins and a low incidence of sexual dysfunction $[10,18,19] . \alpha_{1}$-Adrenergic receptor blockers can be used for the initial treatment of hypertension (and may be preferred in patients with BPH, that is, benign prostatic hypertrophy). They can improve voiding symptoms such as hesitancy, straining, and weak urine flow $[18,19]$.

\subsubsection{Influence on isolated rabbit ileum}

Compound $\mathbf{1 0}$ statistically significantly diminished amplitude of contractions of isolated rabbit small intestine in the range of concentrations $10^{-8}-10^{-5} \mathrm{M}$ from 14 to $35 \%$. At the highest concentration $\left(10^{-5} \mathrm{M}\right)$ the tested compound significantly increased frequency of contractions of isolated rabbit small intestine of about $8 \%$ (Table 4 ).

The compound 11, only given at the highest concentration of $10^{-5} \mathrm{M}$ statistically significantly decreased the amplitude of contractions of isolated rabbit small intestine of $30 \%$, but none of the tested doses of compound 11 influenced the frequency of contractions of isolated rabbit small intestine.

The spasmolytic activity of the tested compounds could confirm that hypotensive activity is caused by $\alpha$-adrenolytic activity and additional spasmolytic one.

Table 4. The prophylactic antiarrhythmic activity in anesthetized rats.

\begin{tabular}{|c|c|c|c|c|c|c|c|c|c|c|c|}
\hline \multicolumn{2}{|c|}{$\begin{array}{c}\text { Concentration } \\
\text { Compounds }\end{array}$} & $\mathbf{0}$ & $\mathbf{1 0}^{-\mathbf{9}}[\mathbf{M}]$ & $\mathbf{0}$ & $\mathbf{1 0}^{-\mathbf{8}}[\mathbf{M}]$ & $\mathbf{0}$ & $\mathbf{1 0}^{-7}[\mathbf{M}]$ & $\mathbf{0}$ & $\mathbf{1 0}^{-\mathbf{6}}[\mathbf{M}]$ & $\mathbf{0}$ & $\mathbf{1 0}^{-\mathbf{5}}[\mathbf{M}]$ \\
\hline $\begin{array}{c}\text { Amplitude } \\
\text { [g] }\end{array}$ & $\mathbf{1 0}$ & 1.43 & 1.56 & 1.53 & 1.31 & 1.55 & 1.29 & 1.63 & 1.10 & 1.72 & 1.11 \\
& & \pm 0.06 & \pm 0.06 & \pm 0.06 & $\pm 0.06^{\mathrm{b}}$ & \pm 0.10 & $\pm 0.05^{\mathrm{a}}$ & \pm 0.10 & $\pm 0.07^{\mathrm{c}}$ & \pm 0.11 & $\pm 0.09^{\mathrm{c}}$ \\
\cline { 2 - 12 } & $\mathbf{1 1}$ & 2.54 & 2.59 & 1.33 & 1.68 & 2.06 & 166 & 2.15 & 2.02 & 2.62 & 1.82 \\
& & \pm 0.28 & \pm 0.22 & \pm 0.09 & $\pm 0.13^{\mathrm{a}}$ & \pm 0.21 & \pm 0.13 & \pm 0.12 & \pm 0.11 & \pm 0.19 & $\pm 0.13^{\mathrm{b}}$ \\
\hline Frequency & $\mathbf{1 0}$ & 12.74 & 12.14 & 11.77 & 12.15 & 12.05 & 12.15 & 12.24 & 11.60 & 11.61 & 10.70 \\
[min $\left.^{-1}\right]$ & & \pm 0.20 & \pm 0.22 & \pm 0.14 & \pm 0.18 & \pm 0.19 & \pm 0.15 & \pm 0.25 & \pm 0.22 & \pm 0.27 & $\pm 0.25^{\mathrm{a}}$ \\
\cline { 2 - 11 } & $\mathbf{1 1}$ & 6.90 & 8.23 & 11.48 & 9.97 & 10.44 & 10.95 & 12.08 & 13.59 & 11.40 & 8.88 \\
& & \pm 0.12 & \pm 0.95 & \pm 1.29 & \pm 1.13 & \pm 1.19 & \pm 1.19 & \pm 1.02 & \pm 0.67 & \pm 1.17 & \pm 0.85 \\
\hline
\end{tabular}

Values are the mean \pm SEM of 4-5 experiments; The statistical analyses were performed using a one-way ANOVA test; ${ }^{\mathrm{a}} \mathrm{p}<0.05 ;{ }^{\mathrm{b}} \mathrm{p}<0.01 ;{ }^{\mathrm{c}} \mathrm{p}<0.001$.

\section{Experimental}

\subsection{Chemistry}

\subsubsection{General}

Melting points were determined on a Boëtius apparatus and have gone uncorrected. ${ }^{1} \mathrm{H}$ - and ${ }^{13} \mathrm{C}$ NMR spectra were recorded on a Bruker $(500 \mathrm{MHz})$ instrument. Chemical shifts are expressed in ppm $(\delta)$ referred to TMS, coupling constants $(J)$ are given in Hz. IR and UV spectra were recorded on Perkin-Elmer and Hewlett Packard 8453 instruments, respectively. IR spectra were recorded in $\mathrm{KBr}$ pallets and wavenumber expressed in $\mathrm{cm}^{-1}$. Elemental analysis was done on AE 1108 Carlo Erba apparatus. Mass spectra were obtained on AMD-604 spectrometer. TLC plates precoated with silica gel $60 \mathrm{~F}_{254}$ were used for monitoring, and silica gel 230-400 mesh was used for flash column chromatography (both from Merck). 


\subsubsection{Materials}

Sodium hydride $(60 \%$ in mineral oil) was supplied by Avocado Res. Chem. Ltd. (+/-)-2(Chloromethyl)oxirane was purchased from Aldrich Chemicals. Fuming nitric acid $(\mathrm{d}=1.52)$, tributyltin hydride, 2,3-dimethoxybenzaldehyde, boron tribromide solution 1.0 $\mathrm{M}$ in DCM, were obtained from Fluka Chemicals. Solvents were distilled and dried if required. Other common materials were commercial products. 2-(2-Methoxyphenoxy)ethylamine and (4-chlorophenoxy)acetonitrile were obtained according to literature procedures $[1,20,21]$. $\left[{ }^{3} \mathrm{H}\right]$ Prazosin, $\left[{ }^{3} \mathrm{H}\right]$ Clonidine and $\left[{ }^{3} \mathrm{H}\right] \mathrm{CGP} 12177$ were supplied by Perkin-Elmer. The reference compound carvedilol was obtained from the Pharmaceutical Research Institute, Warsaw, Poland.

\subsubsection{2,3-Dimethoxy-5-nitrobenzaldehyde (1)}

2,3-Dimethoxybenzaldehyde was converted to 2,3-dimethoxy-5-nitrobenzaldehyde (1) with a yield of $46 \%$ by the method described by Fukuyama et al. [22]. The regioisomer 2,3-dimethoxy-6nitrobenzaldehyde was also obtained with a yield of $36 \%$ [6]. Data for compound 1: Mp $117-118{ }^{\circ} \mathrm{C}$ (AcOEt); IR: 743.3, 979.3, 1246.5, 1280.1, 1336.2, 1484.2, 1520.5, 1585.4, $1687.5(\mathrm{C}=\mathrm{O})$ and 3094.0 $\mathrm{cm}^{-1}$; UV $(\mathrm{EtOH}, \mathrm{c}=0.064 \mathrm{mg} / 10 \mathrm{~mL} ; \mathrm{nm}), \lambda_{\max }: 211(\lg \varepsilon=4.23)$ and $269(\lg \varepsilon=4.34)$; ${ }^{1} \mathrm{H}-\mathrm{NMR}$ $\left(\mathrm{CDCl}_{3}\right): \delta 4.02$ and $4.15(2 \mathrm{xs}, 6 \mathrm{H}, 2 \mathrm{xOCH}), 7.96$ and $8.30(2 \mathrm{xd}, J 2.7,2 \mathrm{H}, \mathrm{ArH}), 10.42(\mathrm{~s}, 1 \mathrm{H}$, $\mathrm{CHO}) ;{ }^{13} \mathrm{C}-\mathrm{NMR}\left(\mathrm{CDCl}_{3}\right): \delta 56.6\left(\mathrm{OCH}_{3}\right), 62.5\left(\mathrm{OCH}_{3}\right), 111.7,115.3,128.8,143.5,153.2,157.2$ and $188.1(C=\mathrm{O})$; MS (EI, $70 \mathrm{eV}), \mathrm{m} / \mathrm{z}$ [\%]: 211 (100, $\left.\mathrm{M}^{+}\right), 193$ (69), 182 (16), 165 (43), 150 (49), 135 (38), 121 (31), 107 (28), 79 (17), 51 (19); HR-MS for $\mathrm{C}_{9} \mathrm{H}_{9} \mathrm{NO}_{5}$; calcd. 211.0481, found: 211.0486.

\subsubsection{2-(Benzyloxy)-3-methoxy-5-nitrobenzaldehyde (2)}

2,3-Dimethoxy-5-nitrobenzaldehyde (1) was subjected to regioselective deprotection of the hydroxyl group according to the literature [22], and 2-hydroxy-3-methoxy-5-nitrobenzaldehyde was produced with a yield of 98\%, $\mathrm{mp} 139-141{ }^{\circ} \mathrm{C}$ (DCM/hexane); IR: 766.2, 957.0, 1087.2, 1099.9, 1205.2, 1267.0, 1345.1, 1464.5, 1530.9, $1654.2(\mathrm{C}=\mathrm{O}), 3080.0$ and $3294.9(\mathrm{OH}) \mathrm{cm}^{-1}$; UV (EtOH, $\mathrm{c}=0.0796 \mathrm{mg} / 10 \mathrm{~mL} ; \mathrm{nm}), \lambda_{\max }: 262(\lg \varepsilon=3.93), 373(\lg \varepsilon=4.03)$ and $419(\lg \varepsilon=4.01) ;{ }^{1} \mathrm{H}-\mathrm{NMR}$ $\left(\mathrm{CDCl}_{3}\right): \delta 4.03\left(\mathrm{~s}, 3 \mathrm{H}, \mathrm{OCH}_{3}\right), 7.94(\mathrm{~d}, J 2.5,1 \mathrm{H}, \mathrm{ArH}), 8.23(\mathrm{~d}, J 2.5,1 \mathrm{H}, \mathrm{ArH}), 10.01(\mathrm{~s}, 1 \mathrm{H}, \mathrm{CHO})$, $11.72(\mathrm{~s}, 1 \mathrm{H}, \mathrm{OH}) ;{ }^{13} \mathrm{C}-\mathrm{NMR}\left(\mathrm{CDCl}_{3}\right): \delta 56.8\left(\mathrm{OCH}_{3}\right), 111.4,118.8,120.5,140.4,149.1,156.9,195.5$ (CHO); MS (EI, $70 \mathrm{eV}), \mathrm{m} / \mathrm{z}$ [\%]: 197 (100, M+), 179 (10), 151 (65), 136 (35), 121 (12), 108 (39), 80 (25), 63 (11), 51 (22); HR-MS for $\mathrm{C}_{8} \mathrm{H}_{7} \mathrm{NO}_{5}$; calcd. 197.0324, found: 197.0321; Anal. calcd. for $\mathrm{C}_{8} \mathrm{H}_{7} \mathrm{NO}_{5}$ : C-48.74, H-3.58, N-7.10, found: C-48.69, H-3.59, N-6.98.

The latter was converted into product $\mathbf{2}$ according to a procedure described in literature [6]. The crude product was crystallized from DCM/hexane to give compound $\mathbf{2}$ (yield 77\%) as a colorless crystalline solid with $\mathrm{mp} 123-124{ }^{\circ} \mathrm{C}$; IR: 744.5, 957.9, 1093.0, 1235.3, 1337.9, 1344.2, $1525.5(\mathrm{C}=\mathrm{C})$, $1691.7(\mathrm{C}=\mathrm{O})$ and $3099.7 \mathrm{~cm}^{-1}$; UV $(\mathrm{EtOH}, \mathrm{c}=0.088 \mathrm{mg} / 10 \mathrm{~mL} ; \mathrm{nm}), \lambda_{\max }: 212(\lg \varepsilon=4.36)$ and 243 $(\lg \varepsilon=4.12) ;{ }^{1} \mathrm{H}-\mathrm{NMR}\left(\mathrm{CDCl}_{3}\right): \delta 4.06(\mathrm{~s}, 3 \mathrm{H}, \mathrm{OCH})_{3}, 5.35\left(\mathrm{~s}, 2 \mathrm{H}, \mathrm{CH}_{2}\right), 7.33-7.38(\mathrm{~m}, 5 \mathrm{H}, \mathrm{ArH}), 7.97$ $(\mathrm{d}, J 2.7,1 \mathrm{H}, \mathrm{Ar} H), 8.25(\mathrm{~d}, J 2.7,1 \mathrm{H}, \mathrm{ArH}) 10.17(\mathrm{~s}, 1 \mathrm{H}, \mathrm{CHO}) ;{ }^{13} \mathrm{C}-\mathrm{NMR}\left(\mathrm{CDCl}_{3}\right): \delta 56.7\left(\mathrm{OCH}_{3}\right)$, 76.6 $\left(\mathrm{CH}_{2}\right), 111.5,115.1,128.7,128.8,129.1,129.6,135.4,143.8,153.4,155.6$ and $188.1(C=\mathrm{O})$; MS (EI, $70 \mathrm{eV}), \mathrm{m} / \mathrm{z}$ [\%]: $287\left(<1, \mathrm{M}^{+}\right), 258$ (1), 175 (16), 132 (9), 91 (100), 65 (10), 40 (12); HR-MS for 
$\mathrm{C}_{15} \mathrm{H}_{13} \mathrm{NO}_{5}$; calcd. 287.0794, found: 287.0783; Anal. calcd. for $\mathrm{C}_{15} \mathrm{H}_{13} \mathrm{NO}_{5}$ : C-62.72, $\mathrm{H}-4.56, \mathrm{~N}-4.88$; found: $\mathrm{C}-62.95, \mathrm{H}-4.66, \mathrm{~N}-4.94$.

\subsubsection{2-(Benzyloxy)-1-methoxy-3-(methoxymethyl)-5-nitrobenzene (3)}

The nitrobenzaldehyde 2 (10.05 g; $0.035 \mathrm{~mol})$ dissolved in dry benzene (40 mL), was added dropwise to the stirred mixture of $\mathrm{Bu}_{3} \mathrm{SnH}(18.5 \mathrm{~mL} ; 0.07 \mathrm{~mol})$ and HMPA $(12.5 \mathrm{~mL} ; 0.07 \mathrm{~mol})$ under an argon atmosphere. The reaction mixture was stirred at $60{ }^{\circ} \mathrm{C}$ for $3 \mathrm{~h}$ until disappearance of substrate (monitoring by TLC). Methanol $(20 \mathrm{~mL})$ was added to the reaction mixture which was then concentrated (rotary evaporator). The crude product was purified by column chromatography (silica gel, eluted with hexane/AcOEt; 3:2), and crystallized from AcOEt/petroleum ether. (2-Benzyloxy-3methoxy-5-nitrophenyl)methanol $(8.7 \mathrm{~g} ; 82 \%)$ was obtained as a brightly-yellow crystalline solid with $\mathrm{mp}$ 67-70 ${ }^{\circ} \mathrm{C}$; IR: 1036.9, 1045.9, 1350.0, 1478.1, 1522.1, $3269.2(\mathrm{OH}) \mathrm{cm}^{-1}$; UV (EtOH, $\mathrm{c}=0.12 \mathrm{mg} / 10 \mathrm{~mL} ; \mathrm{nm}), \lambda_{\max }: 213(\mathrm{lg} \varepsilon=4.32) ;{ }^{1} \mathrm{H}-\mathrm{NMR}\left(\mathrm{CDCl}_{3}\right): \delta 1.93(\mathrm{brs}, 1 \mathrm{H}, \mathrm{OH}), 3.99(\mathrm{~s}, 3 \mathrm{H}$, $\left.\mathrm{OCH}_{3}\right), 4.56\left(\mathrm{~s}, 2 \mathrm{H}, \mathrm{CH}_{2} \mathrm{OH}\right), 5.20\left(\mathrm{~s}, 2 \mathrm{H}, \mathrm{CH}_{2}\right), 7.33-7.39(\mathrm{~m}, 5 \mathrm{H}, \mathrm{ArH}), 7.77(\mathrm{~d}, J 2.7,1 \mathrm{H}, \mathrm{ArH})$, $7.91(\mathrm{~d}, J 2.7,1 \mathrm{H}, \mathrm{Ar} H) ;{ }^{13} \mathrm{C}-\mathrm{NMR}\left(\mathrm{CDCl}_{3}\right): \delta 56.3\left(\mathrm{OCH}_{3}\right), 60.6\left(\mathrm{CH}_{2} \mathrm{OH}\right), 75.3\left(\mathrm{CH}_{2}\right), 107.1,116.2$, 128.5, 128.7, 135.5, 136.6, 143.7, 150.5 and 152.2; MS (EI, $70 \mathrm{eV}), \mathrm{m} / \mathrm{z}$ [\%]: $289\left(<1, \mathrm{M}^{+}\right), 171$ (2), 91 (100), 65 (8), 40 (6); HR-MS for $\mathrm{C}_{15} \mathrm{H}_{15} \mathrm{NO}_{5}$; calcd. 289.0950, found: 289.0956; Anal. calcd. for $\mathrm{C}_{15} \mathrm{H}_{15} \mathrm{NO}_{5}$ : C-62.28, H-5.23, N-4.84; found: C-62.32, H-5.21, N-4.85.

(2-Benzyloxy-3-methoxy-5-nitrophenyl)methanol (8.32 g; $29 \mathrm{mmol}$ ) was dissolved in THF (55 $\mathrm{mL})$ and cooled to $5{ }^{\circ} \mathrm{C}$ (ice/water bath). Sodium hydride (60\% in mineral oil; $1.56 \mathrm{~g} ; 39 \mathrm{mmol}$ ) was added followed by methyl iodide $(6 \mathrm{~mL} ; 97 \mathrm{mmol})$. The reaction mixture was allowed to warm to room temperature and kept for $1 \mathrm{~h}$. Then it was poured into ice cooled water $(300 \mathrm{~mL})$. The product was extracted with DCM (2 x $150 \mathrm{~mL})$. The combined organic layer were washed with water and brine, and then dried over anhydrous magnesium sulphate. After solvent removal (to dryness), the crude product was obtained as oil. The product was passed through a chromatographic column (silica gel, eluent hexane/AcOEt), and crystallized from acetone/petrol ether to give ether $\mathbf{3}(8.3 \mathrm{~g}$; 95\%) as a colorless crystalline solid, $\mathrm{mp} 59-60.5^{\circ} \mathrm{C}$; IR: 700.3, 954.1, 1069.5, 1093.6, 1342.6, 1477.0 and $1525.4 \mathrm{~cm}^{-1}$; UV $(\mathrm{EtOH}, \mathrm{c}=0.107 \mathrm{mg} / 10 \mathrm{~mL} ; \mathrm{nm}), \lambda_{\max }: 213(\lg \varepsilon=4.34) ;{ }^{1} \mathrm{H}-\mathrm{NMR}\left(\mathrm{CDCl}_{3}\right): \delta 3.35$ (s, $\left.3 \mathrm{H}, \mathrm{CH}_{2} \mathrm{OCH}_{3}\right), 3.98$ (s, 3H, $\left.\mathrm{OCH}_{3}\right), 4.38\left(\mathrm{~s}, 2 \mathrm{H}, \mathrm{CH}_{2} \mathrm{OCH}_{3}\right), 5.15\left(\mathrm{~s}, 2 \mathrm{H}, \mathrm{CH}_{2}\right), 7.33-7.41$ (m, 5H, $\operatorname{Ar} H), 7.76(\mathrm{~d}, J 2.7,1 \mathrm{H}, \mathrm{Ar} H), 7.95(\mathrm{~d}, J 2.7,1 \mathrm{H}, \mathrm{Ar} H) ;{ }^{13} \mathrm{C}-\mathrm{NMR}\left(\mathrm{CDCl}_{3}\right): \delta 56.3\left(\mathrm{OCH}_{3}\right), 58.6$ $\left(\mathrm{CH}_{2} \mathrm{OCH}_{3}\right), 68.9\left(\mathrm{CH}_{2} \mathrm{OCH}_{3}\right), 75.2,106.9,116.5,128.4,128.5,128.6,133.4,136.8,143.8,150.6$ and 152.3; MS (EI, $70 \mathrm{eV}), \mathrm{m} / \mathrm{z}$ [\%]: $303\left(<1, \mathrm{M}^{+}\right), 271$ (8), 91 (100), 65 (7); HR-MS for $\mathrm{C}_{16} \mathrm{H}_{17} \mathrm{NO}_{5}$; calcd. 303.1107, found: 303.1114; Anal. calcd. for $\mathrm{C}_{16} \mathrm{H}_{17} \mathrm{NO}_{5}$ : C-63.36, $\mathrm{H}-5.65$, N-4.62; found: C63.24, H-5.76, N-4.71.

\subsection{6. (3-(Benzyloxy)-2-methoxy-4-(methoxymethyl)-6-nitrophenyl)acetonitrile (4) and (3-(benzyloxy)-} 4-methoxy-2-(methoxymethyl)-6-nitrophenyl)acetonitrile (5)

Benzyl derivative $\mathbf{3}$ was subjected to the vicarious nucleophilic substitution of hydrogen with (4-chlorophenoxy)acetonitrile in the presence of potassium $t$-butoxide in DMF according to the procedure described in the literature [23] to furnish a mixture of three products (detected on TLC) as an oil. The oily residue was chromatographed on silica gel using DCM as eluent. Three fractions, of 
chromatographic purity, were obtained: the first was a Thorpe condensation product [24], which was discarded; the second and third were identified as products $\mathbf{4}$ and $\mathbf{5}$. Crystallization from ethanol gave derivative 4 in $29 \%$ yield as colorless crystals, mp 101-103 ${ }^{\circ} \mathrm{C}$ and product 5 as yellow crystals with a yield of $43 \%, \mathrm{mp} 82-83{ }^{\circ} \mathrm{C}$.

Product 4: IR: 699.4, 958.6, 1065.3, 1231.6, 1340.4, 1453.6, 1526.7, $2261.0(\mathrm{CN})$ and $2939.7 \mathrm{~cm}^{-1}$; UV (EtOH, c $=0.0788 \mathrm{mg} / 10 \mathrm{~mL} ; \mathrm{nm}), \lambda_{\max }: 213(\lg \varepsilon=4.44), 285(\lg \varepsilon=3.91) .{ }^{1} \mathrm{H}-\mathrm{NMR}\left(\mathrm{CDCl}_{3}\right): \delta$ $3.37\left(\mathrm{~s}, 3 \mathrm{H}, \mathrm{CH}_{2} \mathrm{OCH}_{3}\right), 4.02\left(\mathrm{~s}, 3 \mathrm{H}, \mathrm{OCH}_{3}\right), 4.12\left(\mathrm{~s}, 2 \mathrm{H}, \mathrm{CH}_{2} \mathrm{CN}\right), 4.35\left(\mathrm{~s}, 2 \mathrm{H}, \mathrm{CH}_{2} \mathrm{OCH}_{3}\right), 5.12$ (s, $\left.2 \mathrm{H}, \mathrm{CH}_{2}\right), 7.36-7.42(\mathrm{~m}, 5 \mathrm{H}, \mathrm{ArH}), 8.00(\mathrm{~s}, 1 \mathrm{H}, \mathrm{ArH}) ;{ }^{13} \mathrm{C}-\mathrm{NMR}\left(\mathrm{CDCl}_{3}\right): \delta 15.3\left(\mathrm{CH}_{2} \mathrm{CN}\right), 58.8$ $\left(\mathrm{OCH}_{3}\right), 61.4\left(\mathrm{CH}_{2} \mathrm{OCH}_{3}\right), 68.5\left(\mathrm{CH}_{2} \mathrm{OCH}_{3}\right), 75.4\left(\mathrm{CH}_{2}\right), 116.7,120.7,121.1,128.4,128.6,128.7$, 128.8, 128.9, 134.9, 135.9, 143.9, 151.8 and 153.8; MS (EI, $70 \mathrm{eV}), \mathrm{m} / \mathrm{z}$ [\%]: $342\left(<1, \mathrm{M}^{+}\right), 321$ (1), 175 (2), 91 (100), 65 (6); HR-MS for $\mathrm{C}_{18} \mathrm{H}_{18} \mathrm{~N}_{2} \mathrm{O}_{5}$; calcd. 342.1216, found: 342.1211; Anal. calcd. for $\mathrm{C}_{18} \mathrm{H}_{18} \mathrm{~N}_{2} \mathrm{O}_{5}$ : C-63.15, H-5.30, N-8.18; found: C-63.25, H-5.42, N-8.16.

Product 5: IR: 734.7, 1084.6, 1233.5, 1290.0, 1334.8, 1521.0, 1576.0, $2251.7(\mathrm{CN})$ and $2927.7 \mathrm{~cm}^{-1}$; UV (EtOH, c = $0.10 \mathrm{mg} / 10 \mathrm{~mL} ; \mathrm{nm}), \lambda_{\max }: 212(\lg \varepsilon=4.37), 246(\lg \varepsilon=4.17), 278(\lg \varepsilon=4.11)$; ${ }^{1} \mathrm{H}-\mathrm{NMR}\left(\mathrm{CDCl}_{3}\right): \delta 3.30\left(\mathrm{~s}, 3 \mathrm{H}, \mathrm{CH}_{2} \mathrm{OCH}_{3}\right), 3.98\left(\mathrm{~s}, 3 \mathrm{H}, \mathrm{OCH}_{3}\right), 4.05\left(\mathrm{~s}, 2 \mathrm{H}, \mathrm{CH}_{2} \mathrm{CN}\right), 4.56(\mathrm{~s}, 2 \mathrm{H}$, $\left.\mathrm{CH}_{2} \mathrm{OCH}_{3}\right), 5.11\left(\mathrm{~s}, 2 \mathrm{H}, \mathrm{CH}_{2}\right), 7.36-7.42(\mathrm{~m}, 5 \mathrm{H}, \mathrm{Ar} H), 7.68(\mathrm{~s}, 1 \mathrm{H}, \mathrm{Ar} H) ;{ }^{13} \mathrm{C}-\mathrm{NMR}\left(\mathrm{CDCl}_{3}\right): \delta 17.5$ $\left(\mathrm{CH}_{2} \mathrm{CN}\right), 56.4\left(\mathrm{OCH}_{3}\right), 58.4\left(\mathrm{CH}_{2} \mathrm{OCH}_{3}\right), 65.2\left(\mathrm{CH}_{2} \mathrm{OCH}_{3}\right), 76.3\left(\mathrm{CH}_{2}\right), 109.2,116.8,119.6,128.4$, $128.6(2 \mathrm{xC}), 128.7(2 \mathrm{xC}), 132.6,136.2,144.9,151.3$ and 152.4; MS (EI, $70 \mathrm{eV}), \mathrm{m} / \mathrm{z}$ [\%]: $342\left(3, \mathrm{M}^{+}\right)$, 91 (100), 65 (6); HR-MS for $\mathrm{C}_{18} \mathrm{H}_{18} \mathrm{~N}_{2} \mathrm{O}_{5}$; calcd. 342.1216, found: 342.1223; Anal. calcd. for $\mathrm{C}_{18} \mathrm{H}_{18} \mathrm{~N}_{2} \mathrm{O}_{5}$ : C-63.15, H-5.30, N-8.18; found: C-63.18, H-5.32, N-8.21.

3.1.7. 4-Methoxy-6-(methoxymethyl)-1H-indol-5-ol (6) and 6-methoxy-4-(methoxymethyl)-1H-indol-5ol (7)

The compounds $\mathbf{4}$ and $\mathbf{5}$ were subjected to reductive cyclization according to a procedure described in the literature [1,20]. Indole derivative 6 was obtained in $67 \%$ yield, as colorless crystals with $\mathrm{mp}$ $105-106^{\circ} \mathrm{C}$ (DCM/petroleum ether), and indole derivative 7 with a yield of $67 \%$, as colorless crystals with mp $118-118.5^{\circ} \mathrm{C}\left(\mathrm{DCM} /\right.$ petroleum ether) or $\mathrm{mp} 120-120.5^{\circ} \mathrm{C}$ (acetone/petroleum ether).

Product 6: IR: 749.0, 957.0, 1054.7, 1102.0, 1354.3, 1457.1, 1518.1, 3266.1, 3383.2 (NH), 3200-3600 $(\mathrm{OH}) \mathrm{cm}^{-1}$; UV (EtOH, c $\left.=0.0686 \mathrm{mg} / 10 \mathrm{~mL} ; \mathrm{nm}\right), \lambda_{\max }: 216(\lg \varepsilon=4.59)$ and $271(\lg \varepsilon=4.27) ;{ }^{1} \mathrm{H}-$ NMR (acetone-d $\left.\mathrm{d}_{6}\right): \delta 3.37\left(\mathrm{~s}, 1 \mathrm{H}, \mathrm{CH}_{2} \mathrm{OCH}_{3}\right), 3.97\left(\mathrm{~s}, 3 \mathrm{H}, \mathrm{OCH}_{3}\right), 4.57\left(\mathrm{~s}, 2 \mathrm{H}, \mathrm{CH}_{2} \mathrm{OCH}_{3}\right), 6.47-6.48$ (m, 1H, H-3), 7.06 (s, 1H, OH), 7.10 (s, 1H, ArH), 7.21 (t, J 2.8, 1H, H-2), 10.03 (brs, 1H, NH); ${ }^{13} \mathrm{C}-\mathrm{NMR}$ (acetone- $\left.\mathrm{d}_{6}\right): \delta 58.0\left(\mathrm{CH}_{2} \mathrm{OCH}_{3}\right), 60.3\left(\mathrm{OCH}_{3}\right), 71.1\left(\mathrm{CH}_{2} \mathrm{OCH}_{3}\right), 98.9,106.6,125.4,121.1$, 122.2, 132.8, 139.0 and 140.1; MS (EI, $70 \mathrm{eV}), \mathrm{m} / \mathrm{z}$ [\%]: 207 (29, $\left.\mathrm{M}^{+}\right), 175$ (100), 146 (39), 132 (45), 104 (16), 91 (11); HR-MS for $\mathrm{C}_{11} \mathrm{H}_{13} \mathrm{NO}_{3}$; calcd. 207.0895, found: 207.0905; Anal. calcd. for $\mathrm{C}_{11} \mathrm{H}_{13} \mathrm{NO}_{3}$ : C-63.76, H-6.32, N-6.76; found: C-63.52, H-6.47, N-7.09.

Product 7: IR: 730.8, 1074.7, 1148.3, 1311.9, 1436.8, 1471.8, 2926.8 and $3366.0(\mathrm{OH}) \mathrm{cm}^{-1}$; UV $(\mathrm{EtOH}, \mathrm{c}=0.064 \mathrm{mg} / 10 \mathrm{~mL} ; \mathrm{nm}), \lambda_{\max }: 213(\lg \varepsilon=4.40)$ and $303(\lg \varepsilon=3.94) ;{ }^{1} \mathrm{H}-\mathrm{NMR}\left(\right.$ acetone-d $\left.{ }_{6}\right): \delta$ $3.31\left(\mathrm{~s}, 3 \mathrm{H}, \mathrm{CH}_{2} \mathrm{OCH}_{3}\right), 3.85\left(\mathrm{~s}, 3 \mathrm{H}, \mathrm{OCH}_{3}\right), 4.79\left(\mathrm{~s}, 2 \mathrm{H}, \mathrm{CH}_{2} \mathrm{OCH}_{3}\right), 6.46-6.47(\mathrm{~m}, 1 \mathrm{H}, \mathrm{H}-3), 6.88$ (s, 
1H, OH), $6.97(\mathrm{~s}, 1 \mathrm{H}, \mathrm{ArH}), 7.12(\mathrm{dd}, J 3.1$ and 2.5, 1H, H-2), 9.84 (brs, $1 \mathrm{H}, \mathrm{NH}) ;{ }^{13} \mathrm{C}-\mathrm{NMR}$ (acetone$\left.\mathrm{d}_{6}\right): \delta 56.6\left(\mathrm{OCH}_{3}\right), 57.6\left(\mathrm{CH}_{2} \mathrm{OCH}_{3}\right), 67.5\left(\mathrm{CH}_{2} \mathrm{OCH}_{3}\right), 101.0,94.9,123.7,113.8,122.7,130.4,140.6$ and 145.7; MS (EI, $70 \mathrm{eV}), \mathrm{m} / \mathrm{z}$ [\%]: 207 (46, $\left.\mathrm{M}^{+}\right), 175$ (100), 161 (13), 146 (52), 132 (80), 118 (14), 104 (34), 91 (5); HR-MS for $\mathrm{C}_{11} \mathrm{H}_{13} \mathrm{NO}_{3}$; calcd. 207.0895, found: 207.0886.

3.1.8. 4-Methoxy-6-(methoxymethyl)-5-(oxiran-2-ylmethoxy)-1H-indole (8) and 6-methoxy-4(methoxymethyl)-5-(oxiran-2-ylmethoxy)-1H-indole (9)

Indole derivatives 6 and 7 were treated with (+/-)-epichlorohydrin in the presence of a stoichiometric quantity of base in dioxane and water according to the procedure described in the literature [1], to give the epoxides 8 and 9 with yields of $44 \%$ and $64 \%$, respectively, as oils of chromatographic purity.

Product 8: IR: 735.9, 1046.1, 1239.3, 1354.2, 1436.5, 1444.6, 1496.7, 1734.1, 2929.0, $3350.4(\mathrm{NH})$ $\mathrm{cm}^{-1} ;{ }^{1} \mathrm{H}-\mathrm{NMR}\left(\mathrm{CDCl}_{3}\right): \delta 2.71$ and 2.87 (part AB of ABX system, $J_{A B}-4.9,4.6$ and 2.7, 2H, H-10), $3.38-3.41(\mathrm{~m}, 1 \mathrm{H}, \mathrm{H}-9), 3.44\left(\mathrm{~s}, 3 \mathrm{H}, \mathrm{CH}_{2} \mathrm{OCH}\right.$ ), 3.98 (dd, $J-11.2$ and 6.3, 1H, H-8), $4.06(\mathrm{~s}, 3 \mathrm{H}$, $\left.\mathrm{OCH}_{3}\right), 4.27$ (dd, $J-11.2$ and 3.2, $\left.1 \mathrm{H}, \mathrm{H}-8\right), 4.61$ (AB system, $\left.J 11.6,2 \mathrm{H}, \mathrm{CH}_{2} \mathrm{OCH}_{3}\right), 6.59-6.60$ (m, 1H, H-3), 7.09 (s, 1H, H-7), 7.09-7.10 (m, 1H, H-2), 8.40 (brs, 1H, NH); ${ }^{13} \mathrm{C}-\mathrm{NMR}\left(\mathrm{CDCl}_{3}\right): \delta 44.6$ (C10), $50.8(C 9), 58.2\left(\mathrm{CH}_{2} \mathrm{OCH}_{3}\right), 60.5\left(\mathrm{OCH}_{3}\right), 70.6\left(\mathrm{CH}_{2} \mathrm{OCH}_{3}\right), 74.9(C 8), 100.0(C 3), 106.5(C 7)$, 124.5 (C2), 121.4, 127.1, 134.0, 141.7, 144.9 (C-3a, 4, 5, 6, 7a); MS (EI, 70 eV), m/z [\%]: 263 (48, $\mathrm{M}^{+}$), 206 (100), 191 (11), 176 (48), 147 (18), 132 (26), 118 (13); HR-MS for $\mathrm{C}_{14} \mathrm{H}_{17} \mathrm{~N}_{1} \mathrm{O}_{4}$; calcd. 263.1158, found: 263.1165 .

Product 9: IR: 728.7, 846.8, 1086.0, 1143.9, 1199.2, 1301.1, 1459.5, 2924.5, $3369.9(\mathrm{NH}) \mathrm{cm}^{-1}$; ${ }^{1} \mathrm{H}-\mathrm{NMR}\left(\mathrm{CDCl}_{3}\right): \delta 2.70$ and 2.86 (part $\mathrm{AB}$ of $\mathrm{ABX}$ system, $J_{\mathrm{AB}}-5.0,4.3$ and $2.7,2 \mathrm{H}, \mathrm{H}-10$ ), $3.38-3.41(\mathrm{~m}, 1 \mathrm{H}, \mathrm{H}-9), 3.42\left(\mathrm{~s}, 3 \mathrm{H}, \mathrm{CH}_{2} \mathrm{OCH}_{3}\right), 3.80\left(\mathrm{~s}, 3 \mathrm{H}, \mathrm{OCH}_{3}\right), 3.96(\mathrm{dd}, J-11.1$ and $6.1,1 \mathrm{H}$, $\mathrm{H}-8), 4.18$ (dd, $J-11.1$ and 3.5, 1H, H-8), 4.84 (AB system, $\left.J 10.8,2 \mathrm{H}, \mathrm{CH}_{2} \mathrm{OCH}_{3}\right), 6.57-6.58(\mathrm{~m}, 1 \mathrm{H}$, $\mathrm{H}-3), 6.79(\mathrm{~s}, 1 \mathrm{H}, \mathrm{H}-7), 7.03(\mathrm{dd}, J 3.1$ and $2.6,1 \mathrm{H}, \mathrm{H}-2), 8.47$ (brs, $1 \mathrm{H}, \mathrm{NH}) ;{ }^{13} \mathrm{C}-\mathrm{NMR}\left(\mathrm{CDCl}_{3}\right): \delta$ 44.7 (C10), 50.6 (C9), $56.0\left(\mathrm{OCH}_{3}\right), 58.1\left(\mathrm{CH}_{2} \mathrm{OCH}_{3}\right), 67.1\left(\mathrm{CH}_{2} \mathrm{OCH}_{3}\right), 75.1(\mathrm{C} 8), 95.0(\mathrm{C} 7), 101.0$ (C3), 123.5 (C2), 121.4, 122.0, 132.3 (C-3a, 4, 7a), 141.6 (C5), 149.5 (C6); MS (EI, 70 eV), m/z [\%]: 263 (M+100), 206 (98), 191 (15), 190 (23), 178 (51), 175 (32), 163 (22), 147 (35), 132 (30), 118 (34), 116 (34), 104 (20); HR-MS for $\mathrm{C}_{14} \mathrm{H}_{17} \mathrm{NO}_{4}$; calcd. 263.1158, found: 263.1148.

3.1.9. (2R,S)-1-(4-Methoxy-6-(methoxymethyl)-1H-indol-5-yloxy)-3-(2-(2-methoxyphenoxy)ethyl amino)propan-2-ol (10) and (2R,S)-1-(6-methoxy-4-(methoxymethyl)-1H-indol-5-yloxy)-3-(2-(2methoxyphenoxy)ethylamino)propan-2-ol (11)

Compounds 8 and $\mathbf{9}$ were converted into the final products $\mathbf{1 0}$ and $\mathbf{1 1}$ using the procedure described in the literature [1]. They were obtained as foams with yields of $70 \%$ and $68 \%$, respectively.

Compound 10: IR: 1023.5, 1053.1, 1223.8, 1250.8, 1353.4, 1453.3, 1503.4, 3350.5 (NH and OH) cm ${ }^{-1}$; ${ }^{1} \mathrm{H}-\mathrm{NMR}\left(\mathrm{CDCl}_{3}\right): \delta 2.17$ (brs, $2 \mathrm{H}, \mathrm{OH}$ and $\left.\mathrm{NH}\right), 2.82-2.88(\mathrm{~m}, 2 \mathrm{H}, \mathrm{H}-3), 3.08(\mathrm{t}, J$ 5.5, 2H, H-4), 3.38 $\left(\mathrm{s}, 3 \mathrm{H}, \mathrm{OCH}_{3}\right), 3.83\left(\mathrm{~s}, 3 \mathrm{H}, \mathrm{OCH}_{3}\right), 4.01(\mathrm{dd}, J 6.9$ and $3.2,1 \mathrm{H}, \mathrm{H}-1), 4.04\left(\mathrm{~s}, 3 \mathrm{H}, \mathrm{OCH}_{3}\right), 3.99-4.02$ (m, 1H, H-2), 4.14 (t, J 5.5, 2H, H-5), 4.26 (dd, $J 7.5$ and 2.7, 1H, H-1), 4.58 (s, 2H, H-20), 6.59-6.60 
(m, 1H, H-13), 6.87-6.96 (m, 4H, ArH), 7.06 (s, 1H, H-18), 7.13-7.14 (m, 1H, H-12), 8.43 (brs, 1H, $\mathrm{NH}) ;{ }^{13} \mathrm{C}-\mathrm{NMR}\left(\mathrm{CDCl}_{3}\right): \delta 48.8(\mathrm{C} 4), 51.8(\mathrm{C} 3), 55.8\left(\mathrm{OCH}_{3}\right), 57.6\left(\mathrm{OCH}_{3}\right), 60.5\left(\mathrm{OCH}_{3}\right), 68.8(C 5)$, 69.5 (C2), 71.3 (C20), $77.1(C 1), 100.1$ (C13), 107.5 (C18), 111.9, 114.1, 120.9, 121.5 (C8, 9, 10 and 11), 124.5 (C12), 126.2, 133.6 (C14 and 19), 121.7, 142.3, 144.7, 148.3, 149.7 (C6, 7, 15, 16 and 17); MS (EI, 70 eV), m/z [\%]: 430 (6, M+), 415 (16), 354 (4), 261 (11), 224 (16), 207 (29), 175 (100), 132 (11), 56 (27); HR-MS for $\mathrm{C}_{23} \mathrm{H}_{30} \mathrm{~N}_{2} \mathrm{O}_{6}$; calcd. 430.2104, found: 430.2106.

Compound 11: IR: 731.5, 1250.5, 1453.8, 1503.8, 3309.5, $3350.7(\mathrm{NH}$ and $\mathrm{OH}) \mathrm{cm}^{-1} ;{ }^{1} \mathrm{H}-\mathrm{NMR}$ $\left(\mathrm{CDCl}_{3}\right): \delta 2.25$ (brs, 2H, OH and $\left.\mathrm{NH}\right), 2.84-2.86(\mathrm{~m}, 2 \mathrm{H}, \mathrm{H}-3), 3.07(\mathrm{t}, J 5.5,2 \mathrm{H}, \mathrm{H}-4), 3.40(\mathrm{~s}, 3 \mathrm{H}$, $\left.\mathrm{OCH}_{3}\right), 3.78$ and $3.82\left(2 \mathrm{xs}, 6 \mathrm{H}, 2 \mathrm{xOCH} H_{3}\right), 3.96(\mathrm{dd}, J 10.2$ and $6.9,1 \mathrm{H}, \mathrm{H}-1), 4.05-4.10(\mathrm{~m}, 1 \mathrm{H}, \mathrm{H}-2)$, $4.12(\mathrm{t}, J 5.5,2 \mathrm{H}, \mathrm{H}-5), 4.16(\mathrm{dd}, J 10.2$ and 3.0, 1H, H-1), 4.80 (s, 2H, H-20), 6.54-6.55 (m, 1H, H13), 6.83 (s, 1H, H-18), 6.86-6.96 (m, 4H, ArH), 7.08 (dd, J 3.0 and 2.5, 1H, H-12), 8.66 (brs, 1H, $\mathrm{NH}) ;{ }^{13} \mathrm{C}-\mathrm{NMR}\left(\mathrm{CDCl}_{3}\right): \delta 48.9(C 4), 51.8(C 3), 55.8(C 23), 56.0(C 22), 58.0(C 21), 67.3(C 20), 68.8$ (C5), 69.5 (C2), 77,6 (C1), 95.0 (C18), 101.0 (C13), 111.9, 114.1, 120.9, 121.5 (C8, 9, 10, 11), 123.6 (C12), 121.4, 121.8, $132.0(C 14,15,19), 142.0,148.3$ (C6, 16), 149.4, 149.7 (C7, 17); MS (EI, $70 \mathrm{eV})$, $\mathrm{m} / \mathrm{z}$ [\%]: 430 (11, M ), 415 (14, $\left.\mathrm{M}^{+}-\mathrm{CH}_{3}\right), 261$ (14), 224 (10), 207 (38), 206 (23), 180 (21), 176 (26), 175 (100), 132 (9), 100 (10), 86 (12), 56 (26); HR-MS for $\mathrm{C}_{23} \mathrm{H}_{30} \mathrm{~N}_{2} \mathrm{O}_{6}$; calcd. 430.2104, found: 430.2118 .

\subsection{Pharmacology}

\subsubsection{Animals}

The experiments were carried out on male Wistar rats (180-250 g) and male rabbits $(2.5-3 \mathrm{~kg})$. The animals were housed in constant temperature facilities exposed to 12:12 light-dark cycle, and maintained on a standard pellet diet, and tap water was given ad libitum. Control and experimental groups consisted of 6-8 animals each. The investigated compounds were administered intravenously at a constant volume of $1 \mathrm{~mL} \cdot \mathrm{kg}^{-1}$. Control animals received the equivalent volume of solvent. All procedures were conducted according to guidelines of ICLAS (International Council on Laboratory Animals Science) and approved by The Local Ethic Committee on Animal Experimentation.

\subsubsection{Reference compound}

Carvedilol was used as a reference drug.

\subsubsection{Statistical analysis}

The data are expressed as the mean \pm SEM. The statistical significance was calculated using a oneway ANOVA. Differences were considered as significant when $\mathrm{P}<0.05$.

\subsubsection{Adrenoceptor radioligand binding assay}

The experiment was carried out on rat cerebral cortex. [ $\left.{ }^{3} \mathrm{H}\right] \operatorname{Prazosin}\left(19.5 \mathrm{Ci} \mathrm{mmol}{ }^{-1}\right.$, an $\alpha_{1^{-}}$ adrenergic receptor), $\left[{ }^{3} \mathrm{H}\right]$ Clonidine (70.5 $\mathrm{Ci} \mathrm{mmol}^{-1}$, an $\alpha_{2}$-adrenergic receptor), and $\left[{ }^{3} \mathrm{H}\right] \mathrm{CGP} 12177$ (48 $\mathrm{Ci} \mathrm{mmol}^{-1}$ an $\beta_{1}$-adrenergic receptor) were used. The brains were homogenised in 20 vol of an ice- 
cold $50 \mathrm{mM}$ Tris- $\mathrm{HCl}$ buffer $(\mathrm{pH} 7.6)$, and were centrifuged at $20.000 \times g$ for $20 \mathrm{~min}\left(0-4{ }^{\circ} \mathrm{C}\right)$. The cell pellet was resuspended in the Tris- $\mathrm{HCl}$ buffer and centrifuged again. Radioligand binding assays were performed in plates (MultiScreen/Millipore). The final incubation mixture (final volume $300 \mu \mathrm{L}$ ) consisted of $240 \mu \mathrm{L}$ of the membrane suspension, $30 \mu \mathrm{L}$ of $\left[{ }^{3} \mathrm{H}\right] \operatorname{Prazosin}(0.2 \mathrm{nM}),\left[{ }^{3} \mathrm{H}\right]$ Clonidine $(2 \mathrm{nM})$ or $\left[{ }^{3} \mathrm{H}\right] \mathrm{CGP} 12177(0.2 \mathrm{nM})$ solution, and $30 \mu \mathrm{L}$ of the buffer containing seven to eight concentrations $\left(10^{-11}-10^{-4} \mathrm{M}\right)$ of the tested compounds. For measuring the unspecific binding, phentolamine, $10 \mu \mathrm{M}$ (in the case of $\left[{ }^{3} \mathrm{H}\right]$ Prazosin), $10 \mu \mathrm{M}$ (in the case of $\left[{ }^{3} \mathrm{H}\right] \mathrm{Clonidine}$ ), and propranolol $-1 \mu \mathrm{M}$ (in the case of $\left[{ }^{3} \mathrm{H}\right] \mathrm{CGP} 12177$ ) were applied. The incubation was terminated by rapid filtration over glass fibre filters (Whatman $\mathrm{GF} / \mathrm{C}$ ) using a vacuum manifold (Millipore). The filters were then washed twice with the assay buffer and placed in scintillation vials with a liquid scintillation cocktail. Radioactivity was measured in a WALLAC 1409 DSA liquid scintillation counter. All the assays were made in duplicate. The radioligand binding data were analyzed using an iterative curve-fitting routine (GraphPAD/Prism, Version 3.0, San Diego, CA, USA). $\mathrm{K}_{\mathrm{i}}$ values were calculated from the Cheng and Prusoff equation [25].

\subsubsection{Effect on normal electrocardiogram (ECG)}

Electrocardiographic measurement was carried out using the Ascard B5 Eco apparatus, standard lead II, and paper speed of $50 \mathrm{~mm} \cdot \mathrm{s}^{-1}$. The tested compounds were administered intravenously in a dose of $1 \mathrm{mg} \cdot \mathrm{kg}^{-1}$. The ECG recording was carried out immediately before and 1, 5 and $15 \mathrm{~min}$ after administration of the tested compounds. The effect of the compounds on rat ECG recording was calculated according to Cambridge et al. [26].

3.2.6. Prophylactic antiarrhythmic activity in a model of adrenaline-induced arrhythmia according to Szekeres and Papp [27]

Arrhythmia was evoked in thiopental (60 mg kg-1, ip) - anaesthetized rats by iv injection of adrenaline $\left(20 \mu \mathrm{g} \mathrm{kg}^{-1}\right)$. The tested compounds were administered intravenously 15 min or orally $60 \mathrm{~min}$ before adrenaline. The criterion of antiarrhythmic activity was the lack of premature beats and the inhibition of rhythm disturbances in comparison with the control group (ventricular bradycardia, atrioventricular block, ventricular tachycardia or ventricular fibrillation). The cardiac rhythm disturbances were recorded for $15 \mathrm{~min}$ after adrenaline injection. ECGs were analyzed according to the guidelines of the Lambeth Convention [28] on ventricular premature beats (VBs), bigeminy, salvos (less than four successive VBs), ventricular tachycardia (VT, four or more successive VBs), and ventricular fibrillation (VF).

\subsubsection{Influence on blood pressure in rats}

Male Wistar normotensive rats were anesthetized with thiopental (50-75 mg kg-1, ip). The right carotid artery was cannulated with a polyethylene tube, filled with heparin in saline to facilitate pressure measurement using the Datamax apparatus (Columbus Instruments). The studied compounds were injected in a single dose of $1.0-0.003 \mathrm{mg} \mathrm{kg}^{-1}$ into the caudal vein or given per os in a single dose of $1.0-0.03 \mathrm{mg} \mathrm{kg}^{-1}$ after a 5 min stabilization period at a volume equivalent to $1 \mathrm{~mL} \mathrm{~kg}^{-1}$. 


\subsubsection{Influence on isolated rabbit ileum}

The influence on isolated rabbit ileum of the investigated compounds on the smooth muscle was investigated on the rabbit small intestine, according to the Magnus' method [29] modified and described by Orisadipe et al. [30] The white rabbits were sacrificed by cervical dislocation and the small intestine was immediately removed, and cut into strips about 3-4 cm long. The isolated strips were incubated in Krebs solution at $37^{\circ} \mathrm{C}$ and aerated with carbogen in special laboratory dishes. The isolated strip of the intestine was placed in a test glass tube with the Krebs solution constantly aerated by carbogen. After 1 hour incubation period, during which the physiological saline solution was changed every $15 \mathrm{~min}$, the influence of the investigated compounds on spontaneous contractions of the rabbit ileum was evaluated. The contraction of the intestine was recorded on a TZ-4100 line recorder via isometric Harvard transducer, at the muscle load of $1 \mathrm{~g}$. The influence of every single dose was recorded for $5 \mathrm{~min}$.

\section{Conclusions}

The results of this study confirmed that the compounds $(2 R, S)-1-(6-$ methoxy-4-(methoxymethyl)$1 H$-indol-5-yloxy)-3-(2-(2-methoxyphenoxy)ethylamino)propan-2-ol (10) and (2R,S)-1-(4-methoxy-6(methoxymethyl)-1H-indol-5-yloxy)-3-(2-(2-methoxyphenoxy)ethylamino)propan-2-ol (11) possess $\alpha$-adrenolytic and weak spasmolytic activities. The introduction of the aminopropanol moiety into position 5- instead of position 4- of the indole ring of the compound (R,S)-9 suppresses $\beta$-adrenolytic activity. The results suggest that the antiarrhythmic and hypotensive effects of the tested compounds are related with their adrenolytic properties, but the pharmacological effects of the tested compounds were qualitatively weaker than those of carvedilol and $(\boldsymbol{R}, \boldsymbol{S})-\mathbf{9}$.

\section{Acknowledgements}

This project was supported by Polish Ministry of Scientific Research and Information Technologies, Grant no. 2 P05F 01028.

\section{References}

1. Groszek, G.; Bednarski, M.; Dybała, M.; Filipek, B. Synthesis and adrenolytic activity of 1-(1Hindol-4-yloxy)-3-\{[2-(2-methoxyphenoxy)ethyl]amino $\}$ propan-2-ol and its enantiomers. Part 1. Eur. J. Med. Chem. 2009, 44, 809-817.

2. Dulin, B.; Abraham, W.T. Pharmacology of Carvedilol. Am. J. Cardiol. 2004, 93, 3-6.

3. Grassi, G.; Quarti-Trevano, F.; Seravalle, G.; Dell'Oro, R. Cardiovascular risk and adrenergic overdrive in the metabolic syndrome. Nutr. Metab. Cardiovasc. Dis. 2007, 17, 473-481.

4. Shannon, R.; Chaudhry, M. Effect of $\alpha_{1}$-adrenergic receptors in cardiac pathophysiology. Am. Heart. J. 2006, 152, 842-850.

5. Kopecky, S.L. Effect of Beta Blockers, Particularly Carvedilol, on Reducing the Risk of Events after Acute Myocardial Infarction. Am. J. Cardiol. 2006, 98, 1115-1119.

6. Groszek, G.; Nowak-Król, A.; Wdowik, T.; Świerczyński, D.; Bednarski, M.; Otto, M.; Walczak, M.; Filipek, B. Synthesis and adrenolytic activity of 1-(1H-indol-4-yloxy)-3-(2-(2- 
methoxyphenoxy)ethylamino)propan-2-ol analogs and its enantiomers. Part 2. Eur. J. Med. Chem. 2009, 44, 5103-5111.

7. Shibata, I.; Yoshida, T.; Baba, A.; Matsuda, H. Reduction of Aldehyde with Tributyltin HydrideHMPA Combined System. Chem. Lett. 1989, 619-622.

8. Goliński, J.; Mąkosza, M. "Vicarious" Nucleophilic Substitution of Hydrogen in Aromatic Nitro Compounds. Tetrahedron Lett. 1978, 37, 3495-3498.

9. Pönicke, K.; Heinroth-Hoffmann, I.; Brodde, O. Differential effects of bucindolol and carvedilol on noradenaline-induced hypertrophic response in ventricular cardiomyocytes of adult rats. $J$. Pharmacol. Exp. Ther. 2002, 301, 71-76.

10. Filipek, B.; Sapa, J.; Malawska, B.; Kulig, K.; Antkiewicz-Michaluk, L. Search for new antiarrhythmic and hypotensive compounds. Synthesis, antiarrhythmic, antihypertensive, and alpha-adrenoceptor blocking activity of novel 1-[(2-hydroxy-3-amino)]propylpyrrolidin-2-one derivatives. Arch. Pharm. 1997, 330, 225-231.

11. Siemieniuk, A.; Szałkowska-Pągowska, H.; Lochyński, S.; Piątkowski, K.; Filipek, B.; Krupińska, J.; Czarnecki, R.; Librowski, T.; Białas, S. Propranolol analogs containing natural monoterpene structures: synthesis and pharmacological properties. Pol. J. Pharmacol. Pharm. 1992, 44, 557-593.

12. Hool, L.C.; Oleksa, L.M.; Harvey, R.D. Role of G proteins in alpha1-adrenergic inhibition of the beta-adrenergically activated chloride current in cardiac myocytes. Mol. Pharmacol. 1997, 51, 853-860.

13. Boyett, M.R.; Harrison, S.M.; Janvier, N.C.; McMorn, S.O.; Owen, J.M.; Shui, Z. A list of vertebrate cardiac ionic currents nomenclature, properties, function and cloned equivalents. Cardiovasc. Res. 1996, 32, 455-481.

14. C armeliet, E. Cardiac ionic currents and acute ischemia: From channels to arrhythmias. Physiol. Rev. 1999, 79, 917-1017.

15. Hariman, R.J.; Gomes, J.A.C.; El-Sherif, N. Catecholamine-dependent atrioventricular nodal reentrant tachycardia. Circulation 1983, 67, 681-686.

16. Maze, M.; Smith, C.M. Identification of receptor mechanism mediating epinephrine-induced arrhythmias during halothane anesthesia in the dog. Anesthesiology 1983, 59, 322-326.

17. Billman, G.E. The effect of adrenergic receptor antagonists on cocaine-induced ventricular fibrillation: Alpha but not beta adrenergic receptor antagonists prevent malignant arrhythmias independent of heart rate. J. Pharmacol. Exp. Ther. 1994, 269, 409-416.

18. Hieble, J.P. Adrenoceptor subclassification: An approach to improved cardiovascular therapeutics. Pharm. Acta Helv. 2000, 74, 163-171.

19. Jain, K.S.; Bariwal, J.B.; Kathiravan, M.K.; Phoujdar, M.S.; Sahne, R.S.; Chauhan, B.S.; Shah, A.K.; Yadav, M.R. Recent advances in selective alpha1-adrenoreceptor antagonists as antihypertensive agents. Bioorg. Med. Chem. 2008, 16, 4759-4800.

20. Grochowski, E.; Eckstein, Z. Synthesis of Some 2,2,2-Trichloro-1,1-bis $(N$ phenoxyacetamido)ethane Derivatives. Bull. Acad. Pol. Sc. 1963, XI(8), 443-446.

21. Augstein, J.; Austin, W.C.; Boscott, R.J.; Green, S.M.; Worthing, C.R. Some Cardiovascular Effects of a Series of Aryloxyalkylamines. I. J. Med. Chem. 1965, 8, 356-367. 
22. Fukuyama, Y.; Iwatsuki, Ch.; Kodama, M.; Ochi M. Katoaka K.; Shibata K. Antimicrobial Indolequinones from the Mid-Indestinal Glan of the Muricid Gastropod Drupella fragum. Tetrahedron 1998, 54, 10007-10016.

23. Mąkosza, M.; Danikiewicz, W.; Wojciechowski, K. Simple and General Synthesis of Hydroxyand Methoxyindoles via Vicarious Nucleophilic Substitution of Hydrogen. Liebigs Ann. Chem. 1988, 203-208.

24. Mąkosza, M.; Ziobrowski, T.; Serebriakov, M.; Kwast, A. Vicarious Nucleophilic Substitution of Hydrogen in Nitrophenyl Toluenesulfonates. Tetrahedron 1997, 53, 4739-4750.

25. Cheng, Y.C.; Prusoff, W.H. Relationship between the inhibition constant (K1) and the concentration of inhibitor which causes 50 per cent inhibition (I50) of an enzymatic reaction. Biochem. Pharmacol. 1973, 22, 3099-3108.

26. Hariman, R.J.; Gomes, J.A.C.; El-Sherif, N. Catecholamine-dependent atrioventricular nodal reentrant tachycardia. Circulation 1983, 67, 681-686.

27. Szekeres, L.; Papp, G. Handbook of Experimental Pharmacology; Schmier, J., Eichler, O., Eds.; Springer-Verlag: Berlin, Heidelberg, Germany, 1975.

28. Walker, M.J.; Curtis, M.J.; Hearse, D.J.; Campbell, R.W.; Janse, M.J.; Yellon, D.M.; Cobbe, S.M.; Coker, S.J.; Harness, J.B.; Harron, D.W.; Higgins, A.J.; Julian, D.G.; Lab, M.J.; Manning, A.S.; Northover, B.J.; Parratt, J.R.; Riemersma, R.A.; Riva, E.; Russel, D.C.; Sheridan, D.J.; Winslow, E.; Woodward, B. The Lambeth Conventions: Guidelines for the study of arrhythmias in ischaemia infarction, and reperfusion. Cardiovasc. Res. 1988, 22, 447-455.

29. Magnus, R. Versuche am überlebenden Dünnalarm von Säugetieren. Pflügers Arch. 1904, 102, $123-151$.

30. Orisadipe, A.; Amos, S.; Adesomoju, A.; Binda, L.; Emeje, M.; Okogun, J.; Wamebe, C.; Gamaniel, K. Spasmolytic activity of methyl angolensate: A triterpenoid isolated from Entandrophragma angolense. Biol. Pharm. Bull. 2001, 24, 364-367.

Sample Availability: Samples of the compounds $\mathbf{1 0}$ and $\mathbf{1 1}$ are available from the authors.

(C) 2010 by the authors; licensee MDPI, Basel, Switzerland. This article is an Open Access article distributed under the terms and conditions of the Creative Commons Attribution license (http://creativecommons.org/licenses/by/3.0/). 